\title{
Study of Work-Related Musculoskeletal Pain and Health- Related Quality of Life among Hospital Workers
}

\author{
Giwon Kim ${ }^{1,2}$, Chun Sun Lee ${ }^{3}$, Kyunghee Lee ${ }^{4}$ \\ 'Department of Physical Therapy, College of Health Science, Korea University, Seoul; ${ }^{2}$ Research Institute of Health Sciences, Korea University, Seoul; \\ ${ }^{3}$ Department of Dental Hygiene, Dong Nam Health University, Suwon; ${ }^{4}$ Department of Physical Therapy, Dong Nam Health University, Suwon, Korea
}

Purpose: This study examined the work-related musculoskeletal pain and quality of life of hospital workers.

Methods: Self-reported questionnaires were sent to 350 hospital workers at Seoul and Gyeonggi-do, of which 341 were returned. The questionnaire had four items that covered the demographic information, areas of musculoskeletal problems, pain rating scale, and quality of life. The analysis was completed using descriptive statistic, and the differences between pain and demographic variables were identified using a chi-square test. The differences between the type of occupation and quality of life were analyzed by one-way analysis of variance and a Kruskal-Wallis test.

Results: The 12-month prevalence of work-related musculoskeletal pain was $86.1 \%$ of physical therapists, $86.5 \%$ of occupational therapists, $77.1 \%$ of dental hygienists, and 75.8\% of nurses. A significant difference in the general and work related variables was observed between the subject with a physical burden and type of occupation. The most affected pain sites of the physical therapist included low back, hand and wrist, shoulder, and neck. The occupational therapists included the hand and wrist, shoulder, neck, but the nurses and dental hygienists reported the shoulder, back, hand and wrist. A significant difference in the quality of life was noted between the subjects in physical therapists and dental hygienists and the subjects in the nurses and occupational therapists $(p=0.00)$.

Conclusion: These findings show that hospital workers appear to be high risk for work-related musculoskeletal pain, and the quality of life of physical therapists and nurses was higher than that of dental hygienists and occupational therapists.

Keywords: Work-related musculoskeletal pain, Health-related quality of life, Hospital workers

\section{서 론}

근골격계 질환은 현대 노동 인구에 영향을 미치는 만성 통증과 신체 장애의 가장 대표적인 원인 중 하나이다. 우리나라 노동부의 산업안 전보건 기준에 따르면 반복적인 동작과 부적절한 작업자세, 무리한 힘의 사용, 날카로운 면과의 신체접촉, 진동 및 온도 등의 요인에 의하 여 발생하는 건강 장애로서, 목, 어깨, 허리, 팔다리의 신경, 근육 및 그 주변 신체조직 등에 나타나는 질환으로 정의된다. 또한 한국산업안 전공단에서는 근골격계 질환을 근육, 힘줄, 신경 등에 일어나는 통증 을 동반한 질환들의 총칭이라 정의하고 있다. 미국산업안전보건연구 원에 따르면 직무관련 특성뿐만 아니라 사회심리적 요인들도 작업관 련성 근골격계 질환에 관련이 있을 수 있으며, 물리적 요인으로 발생 한 증상이 정신사회적 요인에 의해 근육의 긴장을 증가시키고 증상
에 대한 인지를 증가시켜 증상의 지속과 악화를 일으킬 수도 있다. ${ }^{3}$

보건의료와 관련하여 병원에서 일하는 근로자들은 특정한 반복 작업과 불편하고 부자연스러운 작업 자세, 강한 노동강도, 작업할 때 요구되는 과도한 힘, 불충분한 휴식, 추운 작업환경, 손과 팔 부위에 작용하는 과도한 진동 등이 원인이 되어 근골격계 증상과 질환이 발 생한다.4 병원에는 다양한 보건의료 인력이 종사하고 있으며 비교적 안전하고 의료시설 접근성이 높아 근골격계 질환의 위험이 적을 것 으로 인식되어 왔다. 그러나 보건 및 사회복지사업 종사자들의 전체 산업재해 질환자 대비 근골격계 질환자 발생률은 다른 직군에 비해 높은 편으로 거동이 불편한 환자를 돌보고 치료하기 위해 신체적으 로 과도한 부담을 가지는 것으로 파악된다. 또한 병원의 보건의료인 력은 여성 근로자의 비율이 높고 보건의료 직종의 직무에 따라 다양 한 요인에 의해 업무상 질병이 발생할 수 있다. 간호사는 미국산업안
Received Sep 9, 2019 Revised Oct 16, 2019

Accepted Oct 16, 2019

Corresponding author Kyunghee Lee

E-mail lyoonjin@dongnam.ac.kr
Copylight (C)2019 The Korean Society of Physical Therapy

This is an Open Access article distribute under the terms of the Creative Commons Attribution Non-commercial License (Http:// creativecommons.org/license/by-nc/4.o.) which permits unrestricted non-commercial use, distribution, and reproduction in any medium, provided the original work is properly cited. 
전보건청(occupational safety and health administration)에서 작업 관련 성 근골격계 질환 발생위험률이 높은 10 대 직종의 하나로 규정하고 있으며 여성근로자가 대부분으로 물리적, 화학적, 생물학적 위험요인 과 더불어 환자 이동과 부적절한 자세, 반복작업 등의 인간공학적 위 험인자와 교대근무 등의 작업 특성을 포함한 다양한 요인이 복합적 으로 작용하여 관리가 어려운 직업군에 속한다. ${ }^{6,7}$ 물리치료사는 환 자의 치료에 있어서 신체접촉을 통한 물리적인 힘을 사용하는 경우 가 많기 때문에 근골격계에 과도한 부담을 주어 업무관련성 근골격 계 통증 발생 위험이 큰 집단 중 하나이며, 이들의 건강상태는 환자 치료에 있어서 서비스의 질과 환자의 사회복귀에 있어서 직접적인 영 향을 준다. ${ }^{8}$ 치위생사는 치과 의료 전문가로 진료 영역이 구강과 악안 면 영역으로 한정되고 섬세하고 조심스러운 시술이 이루어지는 특성 이 있어 고도의 긴장과 주의력이 요구되며 똑같은 일을 반복하거나 지루하고 단순한 업무를 수행한다. ${ }^{9}$ 치과 진료는 양적, 질적으로 과중 한 신체적 부담을 주며 단순 반복 작업 등 직업 자체의 내적 요인으로 부적절한 진료 자세를 취하게 되며 여러 가지 통증을 유발할 수 있 다. ${ }^{10}$

삶의 질은 인간의 안녕을 통합적으로 설명하는 데 있어서 주관적 이고 객관적인 측면을 모두 포괄하고 있으며, 특히, 건강관련 삶의 질 은 건강관련 문제들의 결과를 주로 반영한 개념이다. ${ }^{11}$ 건강관련 삶의 질은 통증이나 주관적 건강상태, 스트레스에 영향을 미치는 것으로 알려져 있으며 육체노동 근로자들의 경우 외상으로 인한 산업재해 와 사무직 근로자의 근골격계 증상을 중요한 요인으로 보고하고 있 다. ${ }^{2}$ 여성 근로자의 경우 직업 유무와 노동 강도 등의 직업특성에 따 른 건강관련 삶의 질 차이가 존재함에도 불구하고 ${ }^{13}$ 여성이 대다수 를 이루고 있는 보건의료 직종에 종사하는 사람들의 직무에 따른 근 골격계 증상과 건강관련 삶의 질을 연구한 경우는 드물다.

따라서 본 연구는 보건의료관련 전문가들의 근골격계 통증 정도 를 알아보고 근골격계 통증 유무와 건강관련 삶의 질을 비교하고자 하였다.

\section{연구 방법}

\section{1. 연구대상 및 자료수집 방법}

본 연구의 대상자는 서울과 경기지역 종합병원, 준종합병원(재활, 요 양병원 포함), 개인의원 중 임의 편의추출하여 기관에서 근무하고 있 는 병원 근로자 중 보건의료 관련 전문가인 물리치료사, 작업치료사, 간호사, 치위생사를 대상으로 실시하였다. 총 350 명의 병원 근로자들 이 2018년 7월 1일부터 8월 31일까지 총 60일간에 걸쳐 설문을 진행하 였으며, 자기 기입식 설문지로 조사를 실시하였다. 연구자가 직접 방 문하여 연구의 목적과 연구 내용을 설명한 후 설문지를 배부하였고,
연구 목적을 이해하고 자발적 참여동의서를 작성한 후 설문을 실시 하였다. 이 중 346 부를 회수하였으며 응답이 불충분하거나 현재 질병 치료 중인 5명을 제외한 341 명을 대상으로 분석하였다. 연구대상자 들의 일반적인 특성은 Table 1에 정리하였다.

\section{2. 측정도구}

본 연구에 사용한 설문 문항은 대상자의 일반적 특성과 근무관련 특 성, 근골격계 통증, 삶의 질에 대한 설문으로 구성하였다.

\section{1) 일반적 특성과 근무관련 특성}

일반적 특성과 관련된 항목으로는 성별, 연령, 결혼상태, 규칙적인 여 가 및 취미활동, 가사노동시간, 과거 질병 유무, 과거 손상 유무, 육체 적인 부담 등 8 문항으로 구성하였다. 근무 특성과 관련된 문항으로는 직종, 근무처, 총 근무 경력, 근무시간, 근무 중 휴식시간 유무 등 5문 항으로 구성하였다.

\section{2) 근골격계 통증}

대상자의 근골격계 통증을 파악하기 위해 한국산업안전공단에서 제 시한 근골격계 질환 증상 조사표를 이용하였다(KOSHA code H-302012). 이 조사표를 이용하여 지난 1년간 대상자가 자각하는 통증 유 무와 통증 발생 부위, 통증의 특성을 조사하고 통증 발생 부위를 목, 어깨, 팔, 손, 손목, 허리, 다리, 무릎, 발로 분류하였다. 통증 정도를 파 악하기 위해서는 시각적 상사척도(visual analogue scale, VAS)를 이용 하였다.

\section{3) 삶의 질}

삶의 질을 파악하기 위해 세계보건기구의 삶의 질 간편형 척도 (WHOQOL-BRIEF) 한국어판을 사용하였다. ${ }^{14}$ 한국어판 삶의 질 간 편형 척도의 내적 일치도는 크론바하 알파계수(Cronbach's alpha coefficient) 0.898 이었다. ${ }^{15}$ 이 척도의 문항은 총 26 개 문항으로 되어 있으며 전반적인 삶의 질과 건강에 관한 문항 2 개와 4 개의 하위영역(신체적 건강, 심리적 건강, 사회적 관계, 환경 영역)으로 구성되어 있다. 각 문 항별 점수는 전혀 아니다(1점), 약간 그렇다(2점), 그렇다(3점), 많이 그 렇다(4점), 매우 많이 그렇다(5점)의 5점 척도로 되어 있으며 부정 문 항의 경우 역산하여 채점하였다. 총점은 26-130점 사이로 점수가 높 을수록 긍정적인 반응을 의미한다.

\section{3. 분석방법}

연구 대상자의 일반적 특성과 근무관련 특성은 빈도분석을 실시하 여 빈도와 백분율을 나타내었고 일반적 특성과 근무관련 특성에 따 른 근골격계 통증 유무를 비교하기 위해 카이제곱 검정을 실시하였 
Table 1. Distribution of general and work related variables

\begin{tabular}{|c|c|c|c|c|c|c|c|}
\hline \multirow{2}{*}{ Variables } & \multirow{2}{*}{ Categories } & \multirow{2}{*}{$\mathrm{N}$} & \multirow{2}{*}{$\%$} & \multicolumn{2}{|c|}{ Musculoskeletal pain } & \multirow{2}{*}{$\chi^{2}$} & \multirow{2}{*}{$\mathrm{p}$} \\
\hline & & & & Yes & No & & \\
\hline \multirow[t]{2}{*}{ Gender } & Male & 112 & 32.8 & 89 & 23 & 2.34 & 0.31 \\
\hline & Female & 229 & 67.2 & 191 & 35 & & \\
\hline \multirow[t]{5}{*}{ Age (yr) } & $20-29$ & 187 & 54.8 & 152 & 34 & 11.13 & 0.09 \\
\hline & $30-39$ & 111 & 32.6 & 97 & 12 & & \\
\hline & $40-49$ & 36 & 10.6 & 26 & 10 & & \\
\hline & $\geq 50$ & 6 & 1.8 & 4 & 2 & & \\
\hline & Missing value & 1 & 0.0 & & & & \\
\hline \multirow[t]{3}{*}{ Marital status } & Married & 105 & 30.8 & 80 & 24 & 9.67 & 0.14 \\
\hline & Not married & 231 & 67.7 & 197 & 33 & & \\
\hline & Missing value & 5 & 0.0 & & & & \\
\hline \multirow[t]{2}{*}{ Leisure \& Hobby activity } & Yes & 333 & 97.7 & 273 & 57 & 0.17 & 0.92 \\
\hline & No & 8 & 2.3 & 7 & 1 & & \\
\hline \multirow[t]{3}{*}{ House work } & Yes & 267 & 78.3 & 224 & 41 & 2.68 & 0.26 \\
\hline & No & 71 & 21.0 & 54 & 16 & & \\
\hline & Missing value & 3 & 0.0 & & & & \\
\hline \multirow[t]{2}{*}{ Disease diagnosis } & Yes & 3 & 0.9 & 3 & 0 & 5.71 & 0.46 \\
\hline & No & 335 & 98.2 & 275 & 57 & & \\
\hline \multirow[t]{3}{*}{ Injury history } & Yes & 320 & 93.8 & 263 & 54 & 5.06 & 0.28 \\
\hline & No & 20 & 20.0 & 17 & 3 & & \\
\hline & Missing value & 1 & 0.0 & & & & \\
\hline \multirow[t]{5}{*}{ Physically burden } & No & 8 & 2.3 & 6 & 2 & 26.73 & $0.00^{*}$ \\
\hline & Mild & 131 & 38.4 & 95 & 33 & & \\
\hline & Moderate & 146 & 42.8 & 128 & 18 & & \\
\hline & Severe & 51 & 15.0 & 48 & 3 & & \\
\hline & Missing value & 5 & 0.0 & & & & \\
\hline \multirow[t]{4}{*}{ Type of occupation } & Physical therapist & 122 & 35.8 & 105 & 17 & 13.13 & $0.04^{*}$ \\
\hline & Occupational therapist & 74 & 21.7 & 64 & 10 & & \\
\hline & Nurse & 62 & 18.2 & 47 & 12 & & \\
\hline & Dental hygienist & 83 & 24.3 & 64 & 19 & & \\
\hline \multirow[t]{5}{*}{ Working institution } & General hospital & 129 & 37.8 & 105 & 22 & 13.6 & 0.33 \\
\hline & Semi-general hospital & 116 & 34.0 & 95 & 20 & & \\
\hline & Private clinic & 84 & 24.6 & 74 & 10 & & \\
\hline & Others & 9 & 2.7 & 4 & 3 & & \\
\hline & Missing value & 3 & 0.0 & & & & \\
\hline \multirow[t]{5}{*}{ Working duration (yr) } & $<5$ & 190 & 55.7 & 155 & 34 & 3.07 & 0.80 \\
\hline & $5-10$ & 73 & 21.4 & 60 & 12 & & \\
\hline & $10-20$ & 69 & 20.2 & 57 & 11 & & \\
\hline & $>20$ & 8 & 2.3 & 7 & 1 & & \\
\hline & Missing value & 1 & 0.0 & & & & \\
\hline \multirow[t]{5}{*}{ Work hours (daily hour) } & $<8$ & 43 & 12.6 & 32 & 10 & 14.46 & 0.15 \\
\hline & 8-9 & 226 & 66.3 & 192 & 33 & & \\
\hline & $9-10$ & 53 & 15.5 & 44 & 8 & & \\
\hline & $>10$ & 14 & 4.1 & 11 & 3 & & \\
\hline & Missing value & 5 & 0.0 & & & & \\
\hline \multirow[t]{3}{*}{ Rest time } & Yes & 213 & 62.5 & 177 & 35 & 2.09 & 0.35 \\
\hline & No & 107 & 31.4 & 90 & 16 & & \\
\hline & Missing value & 21 & 0.1 & & & & \\
\hline
\end{tabular}

${ }^{*} p<0.05$. 
다. 근골격계 통증 정도와 삶의 질 측정 결과의 정규성 검증을 위해 Kolmogorov-Smirnov 검정을 실시한 결과 삶의 질 총점과 삶의 질 하 위영역 2개(신체적 건강과 환경 영역)만 정규분포를 가정하였고 나머 지 변수들은 정규분포를 가정하지 않았다. 따라서 직종에 따른 통증 정도의 차이를 비교하기 위해 Kruskal-Wallis 검정을 실시하였다. 직 종에 따른 삶의 질 차이를 비교하기 위해 정규분포를 가정한 삶의 질 총점과 신체적 건강, 환경 영역은 일원배치 분산분석하였고 사후검 정은 Duncan's multiple range test하였다. 나머지 삶의 질 항목은 정규 분포를 가정하지 않아 Kruskal-Wallis 검정하였다. 자료의 분석은 SPSS version 23.0 을 사용하였고 $\mathrm{p}<0.05$ 의 유의수준에서 검정하였다.

\section{결 과}

\section{1. 연구대상자의 일반적 특성과 근무관련 특성}

연구대상자는 총 341 명이며 남자 112 명, 여자 229명이었고 평균 나이 는 $30.72 \pm 7.32$ 세였다. 보건의료 직종에 따라 물리치료사 122 명, 작업 치료사 74 명, 간호사 62 명, 치위생사 83 명이었다.

연구대상자의 일반적 특성에 따른 근골격계 통증 유무를 비교한 결과 주관적으로 느끼는 육체적 부담에 따른 차이가 있었다. 육체적 부담이 전혀 없다고 응답한 8명 중 6명(75.0\%), 견딜만하다고 응답한 131 명 중 95명(73.1\%), 약간 힘들다고 응답한 146명 중 128 명(87.7\%), 매 우 힘들다고 응답한 51명 중 48 명(94.1\%)이 지난 1년간 통증이나 불편 함을 호소하였다(Table 1). 육체적 부담이 클수록, 즉 힘들다고 느낄수 록 통계적으로 매우 유의하게 근골격계 통증이 있음을 호소하였다 $(\mathrm{p}=0.00)$.

연구대상자의 근무관련 특성에 따른 근골격계 통증 유무를 비교 한 결과 보건의료 직종에 따른 차이가 있었다. 전체 341 명 중 280 명 (82.4\%)이 근골격계 통증이 있다고 응답하여 많은 수의 보건의료 전 문가들이 통증을 호소하였다. 물리치료사 122 명 중 105 명(86.1\%), 작
업치료사 74명 중 64명(86.5\%), 간호사 62명 중 47명(77.0\%), 치위생사 83명 중 64명(77.1\%)이 근골격계 통증을 호소하였고 통계적으로 유의 하였다 $(\mathrm{p}=0.04)$.

\section{2. 보건의료 직종에 따른 작업관련 근골격계 통증 특성}

보건의료 직종에 따라 근골격계 통증 정도를 시각적 상사척도로 측 정한 결과 작업치료사가 $4.85 \pm 2.17 \mathrm{~cm}$ 로 가장 통증 정도가 심했고 두 번째로 치위생사가 $4.44 \pm 2.46 \mathrm{~cm}$ 였으며 세 번째는 간호사로 $4.33 \pm$ $2.23 \mathrm{~cm}$ 였고 물리치료사의 경우 $3.94 \pm 2.28 \mathrm{~cm}$ 로 가장 통증 정도가 작았다(Table 2). 그러나 직종에 따른 통증 정도의 차이는 통계적으로 유의하지 않았다 $(\mathrm{p}=0.07)$.

직종에 따라 통증을 느끼는 부위를 비교한 결과 모든 직종에서 다 리와 팔/팔꿈치의 통증을 느끼는 대상자가 가장 적었다. 물리치료사 는 허리(51.6\%), 작업치료사는 손과 손목(50.0\%), 간호사와 치위생사 는 어깨 $(45.2 \%, 47.0 \%)$ 의 통증을 가장 많이 호소하였다. 각 직종별로 물리치료사는 허리> 손과 손목>어깨> 목> 다리> 팔 순이었고 작업 치료사는 손과 손목>어깨> 목>허리>다리>팔 순이었다. 간호사와 치위생사는 동일하게 어깨> 허리> 손과 손목> 목>다리>팔 순이었 다. 직종에 따라 통증 부위별 차이를 비교한 결과 손과 손목에서 직 종에 따른 통계적 유의성이 나타났다 $(\mathrm{p}=0.04)$. 물리치료사와 작업치 료사는 절반가량 $(49.2 \%, 50.0 \%)$ 이 손과 손목의 통증을 호소하였으나 간호사와 치위생사는 $33.7 \%, 33.9 \%$ 의 빈도를 나타내었다(Table 2). 그 외 다른 부위들은 직종에 따른 통계적 유의성이 없었다.

\section{3. 보건의료 직종에 따른 삶의 질}

보건의료 직종에 따른 삶의 질을 비교한 결과 직종에 따른 현저한 차 이가 있었다. 전체 삶의 질 합계에서는 물리치료사의 삶의 질이 85.08 \pm 13.87 점으로 가장 높았고 그 다음으로 치위생사의 삶의 질이 높았 다(84.36 \pm 13.52 점). 삶의 질이 가장 낮은 직종은 간호사로 $76.84 \pm 16.14$

Table 2. Work-related musculoskeletal pain by type of occupation

\begin{tabular}{|c|c|c|c|c|c|c|c|}
\hline \multirow[t]{2}{*}{ Variables } & \multirow[t]{2}{*}{ Categories } & $\begin{array}{l}\text { Physical therapist } \\
\qquad(\mathrm{N}=122)\end{array}$ & $\begin{array}{c}\text { Occupational } \\
\text { therapist }(\mathrm{N}=74)\end{array}$ & $\begin{array}{l}\text { Dental hygienist } \\
\qquad(\mathrm{N}=83)\end{array}$ & $\begin{array}{l}\text { Nurse } \\
(N=62)\end{array}$ & \multirow[t]{2}{*}{$\chi^{2}$} & \multirow[t]{2}{*}{$\mathrm{p}$} \\
\hline & & \multicolumn{4}{|c|}{$N(\%)$} & & \\
\hline \multirow[t]{2}{*}{ 12-month prevalence } & Yes & 105 (86.1) & $64(86.5)$ & $64(77.1)$ & $47(75.8)$ & 13.13 & $0.04^{*}$ \\
\hline & No & 17 (13.9) & $10(13.5)$ & $19(22.9)$ & $12(19.4)$ & & \\
\hline \multirow[t]{6}{*}{ Sites of pain } & Neck & $47(38.5)$ & $34(45.9)$ & $26(31.3)$ & $20(32.3)$ & 7.60 & 0.27 \\
\hline & Shoulder & $53(43.4)$ & $35(47.3)$ & $39(47.0)$ & $28(45.2)$ & 0.38 & 0.94 \\
\hline & Arm/Elbow & $16(13.1)$ & $10(13.5)$ & $7(8.4)$ & $9(14.5)$ & 1.61 & 0.66 \\
\hline & Hand/Wrist & $60(49.2)$ & $37(50.0)$ & $28(33.7)$ & $21(33.9)$ & 8.40 & $0.04^{*}$ \\
\hline & Back & $63(51.6)$ & $30(40.5)$ & $34(41.0)$ & $23(37.1)$ & 4.76 & 0.19 \\
\hline & Leg/Foot & $29(23.8)$ & $10(13.5)$ & $19(22.9)$ & $12(19.4)$ & 3.20 & 0.36 \\
\hline Severity of pain & & $3.94 \pm 2.28$ & $4.85 \pm 2.17$ & $4.44 \pm 2.46$ & $4.33 \pm 2.23$ & 7.12 & 0.07 \\
\hline
\end{tabular}

Mean (SD). ${ }^{*} p<0.05$. 
Table 3. Quality of life by type of occupation

\begin{tabular}{|c|c|c|c|c|c|c|c|}
\hline \multirow[t]{2}{*}{ Variables } & \multirow[t]{2}{*}{ Categories } & $\begin{array}{l}\text { Physical therapist } \\
\qquad(N=122)\end{array}$ & $\begin{array}{l}\text { Occupational } \\
\text { therapist }(\mathrm{N}=74)\end{array}$ & $\begin{array}{l}\text { Dental hygienist } \\
\qquad(\mathrm{N}=83)\end{array}$ & $\begin{array}{l}\text { Nurse } \\
(N=62)\end{array}$ & \multirow[t]{2}{*}{$\chi^{2}$} & \multirow[t]{2}{*}{$p$} \\
\hline & & \multicolumn{4}{|c|}{$\mathrm{N}(\%)$} & & \\
\hline \multirow[t]{6}{*}{ Quality of life } & General health $^{+}$ & $6.18 \pm 1.39$ & $5.77 \pm 1.50$ & $6.40 \pm 1.34$ & $5.69 \pm 1.48$ & 11.68 & $0.01^{*}$ \\
\hline & Physical $^{+}$ & $23.02 \pm 4.26^{\mathrm{a}}$ & $21.05 \pm 4.43^{b}$ & $22.80 \pm 4.44^{a}$ & $20.89 \pm 4.82^{\mathrm{b}}$ & 5.30 & $0.00^{* *}$ \\
\hline & Psychological $^{+}$ & $20.20 \pm 4.04$ & $18.75 \pm 3.55$ & $19.64 \pm 3.66$ & $17.71 \pm 4.63$ & 16.08 & $0.00^{* *}$ \\
\hline & Social $^{+}$ & $10.39 \pm 1.80$ & $9.97 \pm 2.08$ & $10.17 \pm 1.74$ & $9.90 \pm 2.49$ & 2.52 & 0.47 \\
\hline & Environmental $^{+}$ & $25.30 \pm 4.68^{\mathrm{a}}$ & $23.38 \pm 4.86^{b}$ & $25.36 \pm 4.61^{a}$ & $22.65 \pm 5.66^{b}$ & 6.13 & $0.00^{* *}$ \\
\hline & Total $^{\star}$ & $85.08 \pm 13.87^{a}$ & $77.95 \pm 16.96^{b}$ & $84.36 \pm 13.52^{\mathrm{a}}$ & $76.84 \pm 16.14^{b}$ & 6.70 & $0.00^{* *}$ \\
\hline
\end{tabular}

${ }^{+}$Kruskal-Wallis Oneway ANOVA, ${ }^{*}$ Oneway ANOVA, a,b Duncan's multiple range test $(a>b),{ }^{*} p<0.05,{ }^{* *} p<0.01$.

점이었고 작업치료사가 $77.95 \pm 16.96$ 점으로 약 1점 정도 높았다. 이러 한 차이는 통계학적으로 매우 유의미하였고 $(\mathrm{p}=0.00)$, 사후검정 결과 물리치료사와 치위생사, 작업치료사와 간호사의 삶의 질이 같은 그 룹으로 묶여졌다(Table 3).

삶의 질 하위영역 중에서도 사회적 관계를 제외한 일반적 건강, 신 체적 건강, 심리적 건강, 환경 영역의 삶의 질은 모두 직종 간의 유의 한 차이가 있었고 $(\mathrm{p}=0.00)$ 모두 물리치료사와 치위생사, 작업치료사 와 간호사의 삶의 질이 유사한 그룹으로 묶여졌다(Table 3).

\section{고 찰}

본 연구에서는 보건의료관련 근로자들의 근골격계 통증 정도를 알 아보고 근골격계 통증 유무와 건강관련 삶의 질을 비교하였다.

작업관련 근골격계 증상의 특성을 살펴본 결과 전체 대상자의 약 $82.11 \%$ 가 지난 1 년간 통증이나 불편함을 호소하였고 그중 남성의 경 우 $79.46 \%$ 가 여성은 $84.51 \%$ 가 근골격계 통증을 호소하였다. 이 결과 는 한 대학병원 보건의료인 310 명을 대상으로 근골격계 통증을 조사 연구한 결과 남자의 $64.6 \%$, 여자의 $74.6 \%$ 가 통증을 호소하였다고 보 고한 연구결과보다 높은 증상 유병률을 나타내었다. ${ }^{16}$ 다른 연구 결 과에서도 대학병원 보건의료인의 근골격계 증상 호소율은 313 명 중 남성의 $44 \%$ 와 여성의 $70 \%$ 였고, ${ }^{4} 1,183$ 명 중 남자 $25.6 \%$, 여자 $63.9 \%$ 로 보고한 연구보다 ${ }^{3}$ 높은 편이었고 통계적으로 유의한 차이가 있었다. 본 연구에서는 성별에 따른 통계학적 차이는 없었으나 남성보다는 여성에게 근골격계 증상 유병률이 높게 나타나 다른 연구결과들과 유사하였다.

본 연구의 보건의료 관련 근로자들은 주관적으로 느끼는 육체적 부담이 크다고 느낄수록 근골격계 증상을 많이 호소하였으며 직종 에 따라서도 통계학적으로 유의미한 차이를 나타내었다. 주관적으 로 육체적 부담을 많이 느낄수록 근골격계 통증을 나타내는 대상자 가 통계적으로 유의하게 많았고 $\left(\chi^{2}=26.73, p=0.00\right)$ 이는 이전의 연구 에서도 ${ }^{4}$ 유사한 결과를 나타내었다 $\left(\chi^{2}=32.08, \mathrm{p}=0.00\right)$. 사무직 근로
자를 대상으로 한 연구에서 육체적 부담을 느낄수록 $(\mathrm{p}=0.035)$, 우울 감이 있을수록 $(\mathrm{p}=0.015)$ 근골격계 증상 호소율이 높다고 보고한 결 과와도 유사하였다. ${ }^{12}$ 이러한 결과는 본 연구에서는 조사하지 못했지 만 우울이나 직무스트레스와도 연결될 수 있으며 통증과 우울, 스트 레스의 상관관계를 나타내는 많은 연구들이 있어 이것을 뒷받침할 수 있다.

직무관련 특성 중 직종에 따른 근골격계 증상 호소에서도 통계학 적으로 유의한 차이가 나타났는데 물리치료사(86.1\%)와 작업치료사 (86.5\%)가 간호사(75.8\%)와 치위생사(77.1\%)보다 근골격계 통증을 더 많이 호소하였다(Table 2). 병원에 종사하는 보건의료인의 직종에 따 라 근골격계 통증을 조사한 연구는 많지 않다. 그중 한 연구는 간호 사의 통증 호소율이 $72 \%$ 로 가장 높았고 전산직 종사자와 영양직 종 사자의 순으로 통증을 호소하였다고 보고하였는데 $(\mathrm{p}=0.001)^{4}$ 아쉽 게도 물리, 작업치료사 등의 의료기사들은 연구대상에 포함되지 않 았다. 또 다른 연구로는 대만의 건강보험 데이터를 이용하여 보건의 료 전문인력 10 개 직종의 근골격계 장애를 비교한 연구가 있다. 이 연 구에서는 치과의사를 기준으로 강직성 척추염, 추간판 탈출증, 목부 위의 장애 등 8 개 질환 유병률을 비교한 결과 물리치료사가 8 개 질환 모두 다른 직종에 비해 유병률이 통계적으로 유의하게 높게 나타났 으며, 의사는 5 개, 간호사는 4 개 질환에서 다른 직종에 비해 질환 유 병률이 높게 나타났다. ${ }^{17}$ 유사한 설계로 인도의 보건의료 전문가의 근 골격계 질환을 비교한 연구에서는 간호사의 근골격계 통증 유병률 이 $30.9 \%$ 로 가장 높았고 물리치료사(30.0\%), 치과의사(28.5\%) 순으로 나타났다. ${ }^{18}$ 본 연구의 결과에서 통계적으로 유의하지는 않았지만 직 종에 따른 통증 정도의 차이는 통증 호소율이 가장 높았던 작업치료 사의 통증 정도가 평균 $4.85 \mathrm{~cm}$ 로 가장 높았고 치위생사 $(4.44 \mathrm{~cm})$, 간 호사 $(4.33 \mathrm{~cm})$, 물리치료사 $(3.94 \mathrm{~cm})$ 순이었다 $(\mathrm{p}=0.07)$. 물리치료사의 경우 근골격계 통증 호소율은 높은 반면 통증 정도는 낮은 편으로 나타나작은 통증을 많이 느끼는 것으로 조사되었다.

근골격계 통증을 주로 호소하는 부위를 직종별로 비교한 결과, 물 리치료사는 허리, 손과 손목, 어깨 순이었고 작업치료사는 손, 어깨, 
목 순이었으며, 간호사와 치위생사는 어깨, 허리, 손 순으로 직종에 따 라 근골격계 통증을 호소하는 부위에 차이가 있었다 $(\mathrm{p}=0.04$, Table 2). 선행연구 결과 물리치료사는 대상자의 절반 이상에서 허리에 통 증을 호소하였고 ${ }^{19,20}$ 어깨, 손과 손목의 순으로 보고되고 있다. 이러 한 결과는 최근 쿠웨이트 물리치료사를 대상으로 한 연구에서 가장 많이 통증을 느끼는 부위는 허리이며 증상은 근육 경련(muscle spasm) 으로 도수 치료와 환자 이동이 가장 대표적인 활동인 것으로 해석된 연구와 유사하였다. ${ }^{21}$ 작업치료사의 경우 손과 손목, 어깨, 목, 허리 순 으로 이전의 연구와 동일하였고 22 물리치료사, 작업치료사는 보건의 료 직종 중 근골격계 통증이 많은 직종 중 하나이다. ${ }^{2}$ 간호사와 치위 생사는 근골격계 통증과 관련한 연구가 비교적 많이 이루어져 있는 분야이다. 간호사는 대부분의 연구에서 어깨의 통증을 가장 많이 호 소하였고 허리와 다리의 통증을 많이 호소하였다. ${ }^{23-25}$ 치위생사 역시 간호사와 마찬가지로 어깨의 통증이 가장 많았고 허리와 목, 다리의 통증을 주로 보고하였다. ${ }^{10,26}$ 이러한 결과는 본 연구의 결과와 매우 유사하여 모든 직종에서 다리와 팔보다는 허리, 어깨, 목, 손의 상지에 대부분 통증을 호소하고 있었다. 특히, 손과 손목 손가락의 통증은 직종에 따라 통계적으로 유의한 차이가 있었고 물리치료사와 작업 치료사는 대상자의 절반 정도가 손과 손목의 통증을 호소한 반면 간 호사와 치위생사는 약 $33 \%$ 가 손과 손목의 통증을 호소하여 물리치 료사, 작업치료사가 손을 더 많이 사용하고 있음을 알 수 있었다. 이 것은 어깨와 손, 손목 등의 근골격계 통증 정도가 심할수록 동작수 행능력이 떨어진다는 연구 결과와 연결해 볼 때 병원에서 근무하고 있는 보건의료 직종 근무자들의 작업관련 근골격계 통증의 예방과 관리는 매우 중요하다 할 수 있을 것이다. ${ }^{27,28}$ 또한 보건의료전문가들 의 근골격계 증상 유병률이 일반 사무직과는 다르게 주관적으로 느 끼는 건강 상태나 육체적 부담, 직무 특성에 따라 달라져 이와 관련한 심도 있는 연구가 필요할 것으로 보인다.

본 연구의 중요한 결과 중 하나는 보건의료 직종 근무자들이 느끼 는 삶의 질이다. 근골격계 질환과 삶의 질에 관한 연구는 환자의 근골 격계 질환이나 통증 여부에 따라 비교한 것이 대부분이며, ${ }^{15}$ 근로자 의 삶의 질에 대한 연구는 우울증이나 직무스트레스와 관련한 연구 가 많다. 그러나 근로자의 직종에 따른 근골격계 질환과 삶의 질에 대 한 연구는 부족한 실정이다. 본 연구에서 나타난 병원의 보건의료 직 종에 따른 삶의 질은 물리치료사의 건강관련 삶의 질이 가장 높았고 치위생사, 작업치료사, 간호사의 순으로 나타났으며 $(\mathrm{p}=0.00)$, 사후검 정 결과 물리치료사와 치위생사의 삶의 질이 유사하였고 작업치료사 와 간호사의 삶의 질이 유사한 것으로 나타났다(Table 3). 본 연구에서 물리치료사의 삶의 질은 85.08 점(평균환산 3.27점)으로 본 연구와 같 은 척도를 사용한 연구에서 보고한 86.23점(통증이 없다고 보고한 물 리치료사), 82.85 점(통증이 있다고 보고한 물리치료사)과 유사하였고 ${ }^{19}$
또 다른 연구에서 보고한 82.87 점과 유사하였다. ${ }^{8}$ 치위생사는 본 연구 의 결과 84.36점(평균환산 3.24점)으로 선행연구들의 평균환산 점수 인 3.1점 또는 3.18점과 유사한 결과를 나타내었다. ${ }^{29,30}$ 임상간호사의 경우 평균환산 점수는 3.05점으로 물리치료사나 치위생사보다 낮게 나타나 ${ }^{31}$ 본 연구의 결과와 유사하였고 다른 직종에 비해 삶의 질이 낮았다. 삶의 질 측정을 위해 많이 사용하고 있는 다른 측정도구인 SF-36 (medical outcome short form 36-item)은 0-100점 사이의 점수를 나타낸다. SF-36으로 측정한 선행연구들을 비교하면 작업치료사의 신체적 건강은 65.42점, 정신적 건강은 63.65점으로 보고되었고 간호 사는 각각 48.5점과 40.9점으로 낮게 나타났다. ${ }^{32}$ 각 직종별로 건강관 련 삶의 질에 연구한 선행연구 결과들은 1-2편 정도로 매우 부족하였 고 삶의 질 측정 도구가 서로 달라 적절한 비교와 해석이 불가능하였 다. 또한 관련 요인에 대한 연구 결과들 역시 서로 다른 변수와 척도 를 사용하여 일정한 패턴을 파악하고 섣부른 판단을 하기는 어렵다 고 판단되었다. 따라서 환자의 진료와 치료 서비스에 질 향상을 위해 서 보건의료전문가의 근골격계 증상과 관련하여 건강관련 삶의 질 특성이나 영향 요인을 파악하기 위해서는 앞으로 좀 더 광범위하고 확대된 연구가 필요할 것으로 생각된다.

본 연구의 제한점은 연구 대상자 표집이 전국 단위가 아닌 서울과 수도권에 제한되었고 직종 역시 물리치료사, 작업치료사, 간호사, 치 위생사로 한정되어 전체 보건의료인의 작업관련 근골격계 증상과 그 에 관련한 건강관련 삶의 질 차이로 일반화할 수 없다는 것이다. 또한 삶의 질에 영향을 미치는 직업 특성과 작업 자세 등을 다양하게 구분 할 수 없었고 대처 방안에 대한 연구도 이루어지지 않아 앞으로 이러 한 제한점들을 보완하여 더 많은 연구가 이루어지길 기대한다.

\section{ACKNOWLEDGEMENTS}

본 연구는 동남보건대학교 연구비 지원에 의하여 수행된 것임.

\section{REFERENCES}

1. Nordin NA, Leonard JH, Thye NC. Work-related injuries among physiotherapists in public hospitals: A southeast asian picture. Clinics (Sao Paulo). 2011;66(3):373-8.

2. Han SH, Noh DH, Son BY et al. Effects of preventive activities for musculoskeletal disorder on occupational and physical therapists pain and job stress. KSOT. 2012;20(1):29-41.

3. Choi YB, Lee SJ, Song JC et al. Association between job-related factors and musculoskeletal symptoms in university hospital healthcare workers. Ann Occup Environ Med. 2012;24(3):217-28.

4. Han KA. Related factors of musculoskelectal symptoms in university hospital workers. JKAIS. 2015;16(3):1928-36. 
5. Park M, Lee EY. Influences of daily life posture habits and work-related factors in musculoskeletal subjective symptoms among hospital employees. Journal of muscle and joint health. 2016;23(2):125-37.

6. Woo NH, Kim SY. Relationship between job stress and work-related musculoskeletal symptoms of hospital nurses. Korean J Occup Health Nurs. 2009;18(2):270-80.

7. Park HH, Yi G. A study on the subjective musculoskeletal symptoms associated with tasks of operating room nurses. J Korean Acad Community Health Nurs. 2005;16(3):351-9.

8. Bae YH, Lee JH, Yoo HJ et al. Associations between work-related musculoskeletal pain, quality of life and presenteeism in physical therapists. Journal of Korean Society of Occupational and Environmental Hygiene. 2012;22(1):61-72.

9. Kim JH, Kim HJ. A study on the musculoskeletal pain experience of dental hygienist's treatment posture. J Den Hyg Sci. 2009;9(4):413-8.

10. Kim MA, Seo HJ. Dental hygienists work on the impact of factors associated with musculoskeletal pain. J Den Hyg Sci. 2012;12(6):558-65.

11. Hwang WJ, Park Y. Factors affecting health-related quality of life on korean blue-collar workers. Korean J Occup Health Nurs. 2015;24(2):94102.

12. Ko DS, Lee DJ, Ko TS. Changes in job stress, self-efficacy, depression and health-related quality of life according to the degree of musculoskeletal symptoms for white-collar workers. JKAIS. 2013;14(6):2935-44.

13. Sohn S. A study on health status and health related quality of life by job characteristics in korean adult women. Korean J Occup Health Nurs. 2009;18(1):33-43.

14. Min SK, Kim KI, Suh SY et al. Development of korean version of WHO quality of life scale abbreviated version(WHOQOL-BREF). J Korean Neuropsychiatr Assoc. 2000; 39(1):78-88.

15. Bahk JW, Roh S. Relationship between self-reported symptoms of workrelated musculoskeletal disorders and health related quality of life. Korean J Occup Environ Med. 2007;19(2):153-63.

16. Heo TY, Seo MW. Characteristics and related factors of musculoskeletal disorder symptoms in hospital workers. Journal of KOEN 2014:311-8.

17. Wang SY, Liu LC, Lu MC et al. Comparisons of musculoskeletal disorders among ten different medical professions in taiwan: A nationwide, population-based study. PLoS One. 2015;10(4):e0123750.

18. Yasobant S, Rajkumar P. Work-related musculoskeletal disorders among health care professionals: A cross-sectional assessment of risk factors in a tertiary hospital, india. Indian J Occup Environ Med. 2014;18(2):75-81.

19. Kim GW, Lee KH. Work-related musculoskeletal pain and health-related quality of life among physical therapists in Korea. J Kor Phys Ther. 2016;28(1):39-45.

20. Edgar R. Vieira SS, Alexandra Belniak et al. Work-related musculoskeletal disorders among physical therapists: An online survey Disabil Rehabil. 2015;38(6):552-7.

21. Alnaser MZ, Aljadi SH. Physical therapists with work-related musculoskeletal disorders in the state of kuwait: A comparison across countries and health care professions. Work. 2019;63(2):261-8.

22. Park J. The research about the musculoskeletal pain and job stress of occupational therapists Inje University Dissertation of Master's Degree. 2010.

23. Park JY, Kwon IS, Cho YC. Musculoskeletal symptoms and related factors among nurses in a university hospital. JKAIS 2011;12(5):2163-72.

24. Park JK. Musculoskeletal disorder symptom factors and control strategies in general hospital nurses. J Korean Soc Occup Environ Hyg. 2014; 24(3):371-82.

25. Jung JS, Eun Y. Factors associate with musculoskeletal symptoms in small and medium sized hospital nurses. The Journal of Muscle and Joint Health. 2017;24(3):159-70.

26. Ha SJ. Factors on prevalance of musculoskeletal disorders among dental hygienists. Dankook University Dissertation of Master's Degree 2003.

27. Gyer G, Michael J, Inklebarger J. Occupational hand injuries: a current review of the prevalence and proposed prevention strategies for physical therapists and similar healthcare professionals. J Integr Med. 2018; 16(2):84-9.

28. An H. Relation of following activities ability and musculo-skeletal pain self-awareness degree of occupational therapist evaluated quickdash. Chungnam National University Dissertation of Master’s Degree 2013.

29. Kim YS. An analysis study of the quality of life in dental hygienists in Seoul. J Denl Hyg Sci. 2005;5(1):39-43.

30. Kim YK. A study on the job satisfaction and quality of life in dental hygienists. JKSDH. 2003;3(2):127-41.

31. Kwon YS. The relationship between occupational stress, depression and quality of life in clinical nurses. JLCCI 2018;18(24):783-97.

32. Kim KS, Choi S. Influence of nurses' sense of coherence on their stress and quality of life. J Korean Acad Nurs Admin. 2011;17(4):493-507. 